\begin{tabular}{|l|l|l|l|l|}
\hline \multirow{2}{*}{ aptara } & CUAN & cuan_1125 & Dispatch: December 10, 2011 & CE: N/A \\
\cline { 2 - 5 } & Journal & MSP No. & No. of pages: 22 & PE: Sarah \\
\hline
\end{tabular}

\title{
PIRACY, CIRCULATORY LEGITIMACY, AND NEOLIBERAL SUBJECTIVITY IN BRAZIL
}

\author{
ALEXANDER S. DENT \\ George Washington University
}

PIRACY'S DIALOGIC SUJECTIVITIES

Bull-rider Daniel had heard only a few songs by César Menotti and Fabiano when he decided to buy a "pirated" copy of the Brazilian duo's first album at a bus station kiosk in the interior town of São José do Rio Preto in 2004. ${ }^{1}$ He paid just 2 reais (about $\$ 1$ ). ${ }^{2}$ He wasn't sure he would like the entire album, and the "official" price was simply too high, having been set by some company that "didn't care what Brazilians could afford." But when song after song from the album went on to become a hit and he wanted to give the disc as a present, Daniel spent 20 reais on an official copy purchased at the mall. He wanted to give something "of good quality" and felt uneasy about giving an illegal copy as a present. At the time, it seemed to me that Daniel's desire to give an "original" CD to a friend was at odds with his earlier celebration of the availability of cheap music in the street in Brazil. However, I soon began to realize that these two apparently opposed subject positions on piracy relied on one another. Furthermore, adding another layer of complexity, participants who primarily occupied either a pro- or an antipiracy position frequently stepped out of character to offer the opposite argument. In seemingly paradoxical ways, workers at antipiracy NGOs would suddenly laud pirates as creative Brazilian geniuses, while purveyors of copied CDs would abruptly fret over the impurity of their "Third World" occupation.

This article analyzes the mutual constitution of these subject positions (which I also refer to as subjectivities or position takings; see Ortner 2005), as well as 
their cooccurrence in economic locations that, at first, appear to be opposed: a pro-intellectual property NGO, versus an example of Brazil's omnipresent informal markets. These sites provide specific and localized instantiations of piracy's complexity, while also pointing to an international discursive space. Both within Brazil and more broadly, in the late 20th and early 21 st centuries, piracy has become central to neoliberal experience on several levels. Piracy - as the term is used in, for instance, the news media, at board meetings, or at hacker conferences - is often thought to comprise several components. These include counterfeiting, copying, smuggling, and trafficking, which are occasionally separated but more often are grouped together. More precisely, piracy involves the production or movement of goods and services by personnel unauthorized by governments or corporations to participate in the circulatory process. The label pirate is nonetheless indiscriminately and pejoratively applied by those seeking to regain control of a given circulatory process, most frequently large companies, and the public sector and nongovernmental apparatuses that support them. The label is frequently grounded in the belief that pirates parasitically appropriate value they did not create, thereby disrupting customary processes of production and consumption. However, those participating in said unauthorized productions and movements (buyers and sellers in "informal" economies or even students sharing music) often proudly appropriate the skull and crossbones. Self-proclaimed pirates point to a broader social purpose beyond their self-interest, such as the "freedom" of ideas, or "social banditry" (Hobsbawm 2000).

Careful scrutiny of piracy is of utmost importance not just because shrill denunciations of it in the press (Phillips 2005) supported by industry "studies" (Friel 2007; Olson et al. 2007) 3 obscure its inner logic. Nor is piracy's analysis merely important because of the impetus its invocation provides to current ominous shifts in international trading practice, such as the new Anti-Counterfeiting Trade Agreement (ACTA), which promises to make international intellectual property (IP) regimes considerably more restrictive. ${ }^{4}$ Rather, understanding piracy is important because its emerging centrality to neoliberalism clarifies recent deep-seated transformations in economics, law, and governmentality. It clarifies the forms of subjectivity available to producers, distributors, and buyers who participate in consumer economies. In its earlier phase, in the 1980s and early 1990s, neoliberalism's proponents sought to "free" markets that had once been controlled by bureaucrats (Biehl 2006:208), withdraw institutional monitoring of economic activity (Morris 2001), and propagate an ethos of "competition" (Storper 2001:107). These combined activities led to transformations that social scientists have critiqued. They 
cuan_1125 can2008.cls December 10, 2011 19:39

CULTURAL ANTHROPOLOGY 27:1

include a dramatic rise of "informal" economies (Centeno and Portes 2006), an unequal distribution of income as well as urban space (Caldeira 2001), and the unevenness of "development" by trickle-down theory (Comaroff and Comaroff 2001). However, current practitioners of neoliberal doctrines including small and large businesses, and NGOs propounding entrepreneurial "participation" and "training" as antidotes to unemployment, have turned to newer tasks.

The increasing prominence of piracy is therefore closely tied to what we might call a "current" form of neoliberalism, which relies on a cluster of interrelated practices. These include the naturalization of "property" (Brown 2003), the increasing importance of highly individualized "consumption" to identity formation (O'Dougherty 2002), and the perceived applicability of "branding" to almost everything (Allison 2010; Manning and Uplisashvili 2008). They also include a widespread belief in the "magical," even redemptive, qualities of "legitimate" circulatory processes that attend to copyright, trademark, brand, and patent (the "circulatory legitimacy" of our title). Finally, the relatively recent capacity of digital technology to assist in the precise copying of not just films and music but also, minimally, of clothes, cellular phones, and cameras frames these other processes. All this, incipient in the rise of neoliberalism but reaching its apogee quite recently, has facilitated seemingly opposed subject positions, which consumers, producers, and suppliers participating in "consumer economies" inhabit in contradictory ways (Dent 2009).

At present, from the perspective of many governments and corporations, the vast majority of the world's consumers have been "pirates" at one time or another. Who has not downloaded an MP3 file without paying, placed "cracked" software onto his or her computer, or purchased a cheap pair of designer sunglasses? The expansion of the "pirate" category to the majority of the world's consumers of public culture can be explained by a paradox. Corporate law firms, self-proclaimed "inventors," and even indigenous tribes avidly protect the "property" (almost everything) of "authors" (almost everyone), ostensibly to foster creativity and justice. The idea is that you must be able to profit from your own creative powers, or you'll simply refrain from exercising them. Also, international corporations and their advertising agencies incite buyers to pursue "legitimate" goods, which, because of their attentiveness to the protection of IP, bring the consumer a "full," or as we shall see, "magical" experience. This is redemption by way of copyright, trademark, patent, and brand.

At the same time, the economistic nature of much statecraft simultane-

ously admonishes that "entrepreneurs" should bring goods "efficiently" to markets 
(Condry 2004). The old principle of efficiency cautions each buyer not to pay too much, because such inefficiencies are bad for the society-as-organism. Today, this cost scolding almost inevitably leads to involvement with things pirated. The "legitimate" is therefore opposed to the degraded experience to be had with what is often touted as an ever-more-dangerous piracy, while the degraded is simultaneously elevated as good economic sense. Adding force to this pinch between degradation and efficiency is digital technology's ostensibly new temptation of its users with illicit circulation and production (lawyer and "Creative Commons" cofounder Lawrence Lessig goes so far as to call file sharing "addictive”; 2004, 297). This new merging of long-standing capitalist practice with late neoliberal "theology" (cf. Weber 1958) and technology is what puts piracy squarely at the center of the subject positions explored in this article's ethnographic cases.

One of the chief factors that places piracy at the center of neoliberal subjectivities in Brazil and elsewhere is the increasing hegemony of IP. Ours is an age in which unions, government-funded educational programs, and evangelical churches encourage members to "participate" in economies for a simultaneously national and international good (Soto 1989). In such circumstances, however, well-established corporations need new ways to determine levels of participation. Banks, credit unions, and International Monetary Fund initiatives peddling "microcredit" may wish that everyone could become an entrepreneur. But if this were to take place, the companies currently at the top of the economy would lose profit. In recognition of this, think tanks funded by international business-interest groups such as the International Chamber of Commerce try to limit participants by eliminating pirates and propounding IP. Applying the label pirate therefore allows powerful institutions to decide which actors are allowed to compete in, and which are to be excluded from, mainstream economic practice. ${ }^{5}$ This provides these institutions with a moral scheme by which those able to protect their IP are allowed to benefit fully from their economic activity, while those unable to do so are not: an ethics of accumulation.

The derogation of piracy therefore provides an important component of its capacity to shape neoliberal experience. This is effected in part from the presentation of the pirate in the news media as an "enemy of all" (Heller-Roazen 2009). The pirate deserves the worst punishments because he or she has apparently foresworn fundamental social norms - property, ownership, and exclusivity. So the figure of the menacing pirate allows a virtuous consumer to take shape, in turn suggesting that the pirate has become the consummate "pariah" neoliberal subject (Comaroff and Comaroff 2001:20). Without piracy, there is no "legitimate" circulation. 
cuan_1125 can2008.cls December 10, 2011 19:39

CULTURAL ANTHROPOLOGY 27:1

Furthermore, the presence of the pirated in informal economies, as we shall see, will be used to keep the informal informal. This leads to another point, important for those interested in the ethnography of IP. Under such circumstances, IP appears as a series of reactions to piracy, rather than as a transhistorical way of generating and protecting creativity. IP's chief purpose thus seems to be the ratification of the control of governments, corporations, and individuals who align themselves with ideologies of "good business practice" (Wang 2003:3, 188). This article will show the ways in which IP regimes enact that control on a quotidian level by shaping participant self-perceptions and frameworks. Piracies are far from tangential or derivative, as they are often portrayed even in sophisticated scholarship (see, e.g., Larkin 2008). On the contrary, piracies are the foil against which the enjoyment of legitimately circulated commodities becomes both possible and necessary.

The two Brazilian sites explored next are useful for analyzing the split subjectivity that surrounds piracy. ${ }^{6}$ In Brazil, "pirated" products are almost everywhere, in urban and rural spaces alike, and people across social classes buy such products. Even more important, the hegemonic national politics of "mixture" in Brazil give piracy a particular urgency. The neoliberal positions analyzed here stretch between piracy as "cultural intimacy" (that which is embarrassing but nonetheless crucial to national identity, as in Herzfeld 1996; Matory 2004), and piracy as a critique of the injustice of the international market, thought to be ruled by large corporations at the expense of an Everyman. In short, in this Brazilian case, the desires both to practice piracy and to eradicate it have local roots. Brazil has, for much of the 19 th and 20th centuries, characterized itself as a zone of mixture in race, music, food, sport, and religion (Collins 2004). However, a more "intimate" fear of overmixture is just as prominent (Schwarz 1992). Current Brazilian consumers therefore experience both pleasure and anxiety about mingling. This means that legitimate or branded goods and services, along with associated practices of their production and consumption, may be locally read as unmixed or pure. This portrays piracy as taking dangerous liberties with modes of production, materials, and product provenance. However, the pirated may be conceived of as perfectly in line with that wonderfully Brazilian way of paying no mind to boundaries.

To examine the current neoliberal paradox where those oriented toward acts of consumption are torn between getting a good deal and receiving a fully consummated commodity experience, I focus on two sites, where the dialogically related subject positions that piracy gives rise to emerge clearly. The first reveals an argument for the sanctity of legitimately circulated products within the context of 32 individuated consumption. Here, piracy constantly threatens circulatory legitimacy 
and, consequently, identity formation itself. This site is an ad campaign against the purchase of what are called "pirated products," a deliberately diverse group of goods that is intended to blur distinctions between the copyrights, brands, patents, and trademarks meant to "protect" the goods. The ads thus participate in a kind of semantic warfare that seeks to apply the term pirated to as broad a range of goods and services as possible, even to those that might, in the past, have been labeled generic (such as medicines). Supplementary to the ad campaign are interviews I conducted in the city of São Paulo beginning in July 2008, with lawyers, economists, public relations consultants, retired police officers, advertising executives, and lobbyists. They reveal beliefs that piracy's minions make off with brands, which in turn is thought to muddy commodity efficacy. It puts both the individual consumer and society, more generally, at risk by supporting drug and gun smugglers, pimps, and racketeers. In this context, part of piracy's local threat lies in the way it allows the public, diffuse, and chaotic "street" made famous by Brazilian anthropologist Roberto DaMatta to invade the private, hierarchical, and orderly "house" (1979).

A body of interviews and observations dating back to 1998 shapes the analysis of my second site, which shows how piracy is a way to be economically "competitive." Workers in this site - a street market - include: those who have recently lost manufacturing jobs in the formal business sector; small business owners who have grown weary of restrictive state regulations; church and community organizers supplementing their incomes; and those who still see themselves as students headed toward more formal careers in education, law, or even medicine but who have so far been unable to enter university. All celebrate their "informal" occupations as antidotes to Brazilian underemployment and corporate price gouging.

Despite the fact that these two sites would seem to be opposites, we will see that subjectivities split; each site has absorbed the critique of the other, and each must respond to contradictory neoliberal injunctions to buy cheaply while preserving the exclusivity of IP. These sites contain antipiracy advocates who suddenly celebrate piracy, and propiracy workers and buyers in the informal economy who ruefully acknowledge the inadequacy of their jobs and goods.

\section{EMERGENT ANXIETIES}

Understanding the two sites I lay out in this article requires returning to a time before hyperbolic statements about the provenance of "pirated copies." When I first started studying music in Brazil in 1998, contraband CDs showed up everywhere. The vendors (often called camelôs, a frequently pejorative term for ambulatory sellers of "cheap and imitative goods," [see Houaiss 2001], although also used as 
cuan_1125 can2008.cls December 10, $2011 \quad 19: 39$

CULTURAL ANTHROPOLOGY 27:1

collective noun in the state of São Paulo) clustered around bus stations. Most fans and musicians claimed indifference about where they had purchased their music.

Neoliberalism's increasing focus on IP quickly brought piracy and the moralities of digital mediation to the center of Brazilian subjectivity. In a nation that consumed music largely produced within Brazil by Brazilians, the discourse on copying, production, and circulation polarized. On one side, some performers and journalists began to trumpet informal economies as creativity's saving grace. In 1999, for instance, Brazilian rocker Lobão (Big Wolf) cast off his record company to distribute his newest disc by way newspaper stands, which appeared to be somewhat close to the street-market kiosks that sold illegal copies. He decried, as he did so, the evils of his label (Lobão et al. 2000). For Lobão, his recording company's propensity to exaggerate or downplay sales figures according to how much it had invested in a particular record showed how Brazil had replaced its military dictatorship (which ended in 1985) with a corporate one. For the executives and their media representatives to complain about what was happening by the bus station was both hypocritical and authoritarian, he argued.

But complain they did. At the same time as Lobão and his supporters were praising the streets, the industry preached perdition. A series of NGOs funded by the mouthpieces of big media conglomerates (such as the Recording Industry Association of America) began to advocate for the "intellectual property" of artists, hanging posters in legitimate record stores showing duct tape over the mouths of famous Brazilian singers. Concurrently, stories of police raids of the camelôs made the rounds in the news media. These stories tied illegally copied CDs to "organized crime" and, thereby, to the degeneration of Brazilian society (see also Schneider and Schneider 2008). More personal injuries were apparently multiplying too. For example, one of Brazil's most widely read news magazines compared the supposedly inevitable imperfections of pirated CDs to the scratches on old vinyl LPs and claimed, quite falsely, that repeated playing of such subpar merchandise would require expensive servicing of stereo equipment (veja 1999). The message was clear; piracy was becoming every individual consumer's burden.

In the late 20th century, therefore, informal economies and their goods, long a significant component of the political and economic landscapes in Brazil (Gay 2006), were beginning to generate discourses of redemption and perdition, celebration and complaint. Connected with this, the drive to classify most forms of expressive and material culture as IP and then stringently "protect" them was butting up against the injunction to produce as cheaply as possible. The stakes were 
be the very thing that would pull Brazil out of its slumber into postauthoritarian prosperity. However, under this rubric, those involved in the sale of illegal copies, not just of records and films but of tennis shoes, soccer shirts, sunglasses, and a host of other products, presented a problem. Were they doing what they were supposed to be doing by being dutiful entrepreneurs? Or were they ruining a delicate society in need of "international investment" by violating the sacred principles of IP?

\section{BOUNDARY VIOLATION AND POLICING IN BRAZIL}

Although these questions seemed new, the terms in which they were being asked were not. Early 20th-century modernist poet Oswald de Andrade famously proposed, in his Cannibalist Manifesto, that Brazilians behave precisely as their indigenous ancestors did. They eat other human beings (cultures) to absorb their flesh (or "essence"; see Andrade 1970) and thereby create something new. The sexuality of this mixing was and remains significant as the verb comer means both "to eat" and "to penetrate" in Portuguese (Veloso 2002). Today, such discourses still provide clear footing for "consuming" across various classes of phenomena. Far from being derivative of Europe and later of the United States, Brazil comes instead to be defined by its propensity for having sex with others - for "eating" them.

This template is currently understood to apply to many phenomena. These include Boas-trained Brazilian anthropologist Gilberto Freyre's "big house," where the seduction of black female slaves by male Portuguese owners created a stronger race (Freyre 1986). Across such sites we can point to arguments for the social benefits of keeping unexpected bedfellows. In the context of a more traditional European nationalism, such unexpectedness is portrayed as aesthetically dangerous or messy. But here boundary crossing is not only creative but also downright sexy. An inherent propensity to flout generic proprieties in race, social class, gender, soccer, music, and food is frequently scored for a sexualized nation, and not just for tourists (Parker 2009). Celebrations of Brazil as hacker land (as in Dibbell 2004) or the flap over then minister of culture Gilberto Gil's signing over of a single song to a Creative Commons license recycle these tropes with clarity and frequency. The mixture that results from deliberately breaking down boundaries is framed as a source of Brazilian singularity. Stereotyped views of Brazil at home and abroad frequently go no further.

But any redemptive politics of boundary breaking is coconstituted by a strict policing of limits. There must be something to be between. And despite the fact that the policing of boundaries is seldom viewed abroad as emblematically 
cuan_1125 can2008.cls December 10, $2011 \quad 19: 39$

CULTURAL ANTHROPOLOGY 27:I

Brazilian, it is every bit as important to national identity. This approach appears most clearly in protracted late-20th- and early 21 st-century hand-wringing over "tradition" in various guises (Oliven 1992). In musical cases, the argument is often that "urbanization" of once Brazilian musical forms has led to the cultural subservience of Brazilians to ineluctable modernizing, linked to foreign powers. Such worries about being cavalier with boundaries find reinforcement in continued readings of Euclides DaCunha's Rebellion in the Backlands (1944), a late-19thcentury account of the massacre of a city of zealots by urban decadents. Here, DaCunha argues that inattentiveness to boundaries (indexed, e.g., by the racially mixed northeastern peasant and his bastardized messianic Christianity) produces degenerate and religiously medieval monsters. But no one escapes criticism in this book because the urbanites, by mingling European desires for uniformity with tropical profusion, are both fearful and capriciously murderous. In this and other instances, breaking down boundaries is seen to be both ill-advised and particularly Brazilian. Where promiscuity is celebrated in the previous framing of Brazilian self-understanding, here, monogamy has its virtues.

These sexualized practices of limit violation and policing ground neoliberal Brazilian strife over piracy. The Brazilian voices we are about to hear are not simply parroting international concerns but are commenting on localized approaches to identity, further reinforcing the fact that neoliberalism needs to be thought against and through its local instantiations. The two sites to which we now turn have been selected because they reveal pro- and antipiracy beliefs in their most pronounced forms. However, as with Daniel, these positions are unstable; off-camera, the antipiratical ad campaign briefly celebrates the precision of good copying, while the producers and buyers of the informal economy frequently equate the pirated with degradation.

\section{“WITH PIRATED PRODUCTS, THERE'S NO MAGIC!”}

Should the responsible Brazilian buy the brand or take the fake? Let's start with the former. To pay homage to IP, each consumer must cultivate a constant vigilance for violations of its principles. Brazil, the land of mixture qua hypersexuality, is a veritable minefield. The redemptive "magic" of legitimately circulated goods is continually beset by degraded thieves. We clearly see this on the set of an ad campaign sponsored by Brazil's media meganetwork $O$ Globo, and an NGO, the National Antipiracy and Illegality Forum (FNCP).

The FNCP is one of many antipiracy NGOs currently operating in Brazil, 
the most successful and visible. It is headed by Roberto, a lawyer, economist, and business school professor. Roberto's law practice, he proudly informs me, frequently brings him to New York City, oddly presented by him as a mecca for respect of the branded and copyrighted, a contention the absurdity of which underscores Roberto's embarrassment at Brazil's particular penchant for piracy (i.e., piracy's cultural intimacy). ${ }^{8}$ Roberto is supported by a small team of public relations experts and advertising consultants as well as a host of organizations from Europe, Japan, and the United States.

For the ads I analyze here Roberto's team assembled representatives from seven Brazilian industries that consider themselves vulnerable to "piracy." These include the music and movie industries, and the sunglasses and auto parts industries, among others. In a cavernous studio in the city of São Paulo, a group of actors, producers, makeup artists, and customer relations representatives has gathered on three nights in October 2008 to assemble seven 30-second videos that will begin airing in January 2009.

Because piracy is both a constant threat and a temptation, the FNCP seeks to teach consumers to buy products through legitimate circulatory processes; goods thus purchased are the only ones that are "magical." Each of the seven ads follows a similar structure. In all ads, a magician in a tuxedo attended by a woman in a red dress proposes with flair to use "pirated products" for various purposes. His voicing lays out the dialogic nature of the subject positions we are analyzing, because his discourse cuts two ways; in introducing each ad the magician plants the seeds of his own failure, but he does this in an excited way.

At the opening of the auto parts ad, for example, he proclaims: "And now, an old trick of vehicular maintenance - using parts of doubtful origin in this particular vehicle" (emphasis added to point out the pejorative terms oddly being pronounced with joy). Meanwhile, the female assistant lasciviously removes a tire from a tiny car piloted by a grinning simpleton, whose acceptance of piracy-based auto repair appears to be carnally motivated. Here is a stereotyped Brazilian seduction. True to form, the magician's prosody continues to belie his content, splitting him in two. He is stating with excitement that he is using "tricks" and parts "of doubtful origin." In this way, the short's producers argue that the consumption of pirated products divides the consuming Brazilian into one who both wants to believe in the product, and one who knows it cannot possibly work. Here, the need for piracy manifests itself not only in the old-fashioned search for a deal but also in the celebration of Brazilian mixture; this product is not only cheaper but also is "just as good," is locally made, and is sexy, to boot. 
cuan_1125 can2008.cls December 10, $2011 \quad 19: 39$

CULTURAL ANTHROPOLOGY 27:1

At the beginning of each process (auto repair, pressing "print” on your computer, or playing a DVD, for example), the assistant looks on with anticipation; the magician's promise apparently pleases her. However, after the puff of smoke meant to produce the desired effect, something untoward occurs - the car's engine bursts into flames, or after pressing "play" on the DVD player, the TV intones that this illegal copy will directly fund “organized crime.” The magician's expression then becomes one of embarrassment as well as disgust. He has failed to perform for his assistant as promised. He then reverses his previous excited stance, and his delivery aligns with the negative vocabulary he used before. He now offers a warning, wagging his finger: "With pirated products, there's no magic." The real magic is in the fully consummated consumption that comes from buying a licit good - an act that piracy has foreclosed.

The message here is that the consumer must be on guard against a constant threat, not only of the informal economy with all its copying and theft but also against his own impulse that he is getting a locally made and even sexy "deal," allied with the typically Brazilian tendency to ignore boundaries - in this case, the boundaries that define legitimate consumption. Here, as a buyer, the mixing so often touted as a Brazilian virtue in the media brings nothing but trouble.

Another example forefronts this trouble. In one ad the magician proposes to transform his "lovely assistant" into an even prettier "doll" by placing her in a black box with a pair of "pirated" sneakers, some sunglasses "made with contaminated raw materials," and a few pirated soccer jerseys. Once again, the appeal is sexual; the magician winks at the camera to signal his anticipation of his already lovely assistant's soon-to-be enhanced attractiveness. She understands what's at play, leering at the camera. The box turns, and we hear "abracadabra." The assistant then emerges covered with cuts and bruises, wearing a torn dress, a pair of glasses containing eyeballs hanging from springs, and a shredded tennis shoe. She limps and wobbles, far too demented for intimacy, and requiring assistance from the repulsed magician. This act of mixture has produced a jumbled monster as from DaCunha's pages. So, by being let down by piracy, we come to know what good and just consumption ought to feel like. Buying the real thing becomes knowable through the disappointment that lurks in taking the fake.

The ending that caps off all the shorts further underscores piracy's threat to Brazilian culture. The magician, now dressed as a civilian, sits on a sofa in a living room with his spouse, the assistant. The room is orderly, and the mood has moved to chaste. The husband, who succumbed to the temptation to consume piracy, looks embarrassed, while his wife looks angry. There has been an infidelity. The FNCP's 
logo and hotline for reporting piracy flash on the screen as a narrator entreats: "Don't make your life into a show for piracy." In this retreat to the domestic, piracy has mixed DaMatta's "street" with the "house," bringing disorderly and dangerous pirated goods into the living room. The goods have violated the principle of monogamy that governs the antimixing portion of the Brazilian cultural field, and has thus denied the possibility of a consummated act of consumption with its redemptive magic. We have seen what consuming legitimate and branded products ought to be. We should have seen through the illusions.

If we consider what is taking place at the margins of the filming of these ads, however, this advertising campaign is far from coherent. It contains contradictory off-stage celebrations of illicit use, sale, and copying. One experienced TV producer celebrates an employee who "copies" objects needed for filming ads - enormous brand-name pens that write (Bic), tremendous women's shoes (Nike), and tiny cars (Ford). This "artist of the copy" is surely a pirate, too, the producer excitedly announces to his appreciative audience of customer service representatives, who giggle at the meticulousness involved in reproducing a brand-name car down to its tiny hubcaps. And later, in even stronger support of the piratical, the makeup artist wonders what on earth the multinationals thought would happen when they went to Asia to cut costs. For starters, they fired thousands of Brazilian workers, making them poor and angry. But they also engaged the Asians' sense of profit. Of course those overseas factories that normally make licit goods also make goods for informal markets after hours. Those multinationals deserve to be pirated for being so cheap.

On the set, this ad campaign briefly doubles back on itself to actually promote the pirated, evidencing the simultaneity of seemingly opposed subject positions that piracy brings forth. In this zone of apparently unitary opposition to piracy, subject positions are contested and unstable: the knowledge that piracy produces impotency, inefficacy, and personal qua national ruin attempts to distance itself from but cannot obliterate the desire to partake of the sexiness of Brazilian boundary violation, the urge to get something for less, and internationalized notions of profitability. This contestation emerges as well in Campinas's camelódromo, where piracy is by and large a social good, although it sometimes harmonizes with the ideologies we have just explored, as a dangerous embarrassment.

\section{"WE WANT TO WORK IN PEACE"}

In our second site the Brazilian should just take the fake. Any pejorative sense of piracy seems to reach its epistemological limit at the Popular Shopping Center 
cuan_1125 can2008.cls December 10, 2011 19:39

CULTURAL ANTHROPOLOGY 27:I

of Campinas, an ideal location for exploring Brazil's propiratical discourses. This is where business owners, workers, shoppers, and suppliers align informality with "entrepreneurship" and pride in "work." The market itself is a covered fiberglass and galvanized metal structure that snakes around the central bus station, dominating the downtown area just as an informal economy dominates the center of most Brazilian cities. In Campinas, a city of about 1.5 million, the camelódromo contains about 2,000 numbered stalls. ${ }^{9}$ Here, the brazen flouting of the legitimately circulated becomes both proud brasilidade (Brazilianness) and good economic sense.

The more obvious aspects of Campinas's informal economy set the scene for understanding the positions associated with piracy in this particular site. On every day but Sunday, the camelódromo bustles with people across social classes who are shopping for a variety of goods. These include running shoes, backpacks, pens, watches, large-screen TVs, fresh fruits and vegetables, MP3 players, digital cameras, printer cartridges, and cigarettes. The space is a jumble. Stalls display goods with limited attention to category: cameras, MP3 players, pens, and backpacks appear side by side. In those stands that sell films and music, the discs are disorganized.

The disorderly nature of the space is described by the camelôs and their clients as being the way Brazilians work: let the riotousness of Brazilian nature take its course. Thus, camelos and their clients merge what they are doing with Brazilian creativity and inattention to boundaries. This useful failure to attend to regulations has allowed them to discover rule-breaking solutions to the problem of how to get name-brand and popular items cheaply. "Do you think for a minute I'm going to pay those ridiculous prices across town?" one university student asks me rhetorically. By proving that things can be done more cheaply, the camelô indicts the high cost of goods and services in Brazil. Nor is this the only ill tackled here. Customers and sellers continually restate the way in which this informal economy solves current Brazilian problems of high unemployment. We would all be "on the streets" if we were not "being good businessmen here," I heard time and again.

The notion that the licit shopping mall across town offers conveniences and protections unavailable at the camelódromo is met with scorn. The means of payment here is flexible; if you don't have the cash, just pay by credit card, because many of the kiosks have card readers. Contrary to the FNCP's impotency-inducing explosions, if something you buy at the Campinas camelódromo breaks you bring it back for an instant exchange. As Marcos of box 384 tells me, as he stamps my DVD purchases with the name and number of his stall, shop owners take pride in their 40

"guarantees"; if something doesn't work, he'll replace it. Similarly, the owner of a 
nearby electronics kiosk informs me that he can now even take things all the way to the original stores where he bought them in Paraguay. These guarantees are often confirmed by those who purchase goods. Shoppers inform me that if, for example, they had to deal with Sony's customer service representatives when their digital camera broke, they'd be waiting for weeks. And they would be disappointed at the end of the process. Here, however, they simply return to the booth where they bought the offending product and exchange it for a new one.

Storeowners will go far to obtain "customer satisfaction.” Antônio, a retired university administrator, described dropping the digital camera he had recently bought at the camelo. Naturally, it stopped working. Feeling somewhat guilty, he nonetheless returned to the kiosk where he had bought it, feigning ignorance. The owner asked no questions and put in a new memory card, saying, "I think this will work, but if it doesn't, bring it back next week." Antônio has not returned. The consequences of such policies go beyond mere efficiency in service. Numerous shoppers questioned over the last ten years in visits to the camelódromo claim that they "establish a relationship" with "their" shopkeeper that is much closer than any they could establish at the impersonal mall across town. The warm embrace of the camelô thus dovetails with discourses of "cordiality" as fundamental to Brazilian social relations (Holanda 1995). Buyers and sellers explained to me that the camelô's system in Brazil resembles the formal economy in developed countries, where big companies like Sony actually pay attention to individual customers. However, Sony doesn't care about Brazilians, who must improvise.

As in our previous site, we find the same split in subjectivity. In the camelódromo the dialogic tension between circulatory legitimacy and piracy also requires constant vigilance, although in this location it is a vigilance of a slightly different sort. Over each entrance, in addition to the suggestion that you smile because "you are being filmed," another sign states that "we want to work in peace" (emphasis added). This is signed by "the workers of the informal economy of Campinas," known as STEIC. ${ }^{10}$ Peace is not being used metaphorically. The presence of violence in the camelódromo requires that shopkeepers, suppliers, and even consumers remain watchful, because the state (in the form of the civil police) or other shopkeepers might do something rash at any time. The violence perpetrated by the state is directly blamed on NGOs like the FNCP, which push local police to make raids, punishing violators of IP, while encouraging competing stalls to "inform" on one another through antipiracy hotlines (like the FNCP's). During the raids, people may get hurt or, more seriously, have to spend time in notoriously dangerous prisons. The justification for such raids continues to be "piracy." Local papers 
cuan_1125 can2008.cls December 10, 2011 19:39

CULTURAL ANTHROPOLOGY 27:1

reinforce this by lauding the confiscation and destruction of large numbers of "pirated" goods. Here, therefore, the split subjectivity, for sellers especially, lies in believing that what you're doing makes good economic sense but knowing that a system that ostensibly supports such good sense for some reason does not support you.

The violence between shopkeepers within the camelô is more personal in cause and more fatal in effect than punitive police raids. It is the result of a struggle over whether, and how much, to formalize and what shape that formalization should take. For instance, many camelódromo shopkeepers agree that they want to pay taxes and have wanted to do so for some time. They believe this would allow them access to a better health plan and more convenient bathrooms. But the precise nature of the formalization process is contested, and two factions vie for control. On one side, a community organizer named Carol heads a "society" of workers. She collects weekly "dues" from each stall but is unable to tell anyone precisely where these dues go. The few willing to discuss the matter speculate that such fees are most likely given to local politicians and police, because stall owners that oppose Carol are often raided by police the day after their transgression. On the other side of an increasingly entrenched battle, a new workers' "union," officially recognized by the state and supported by one of Brazil's two largest labor unions, struggles for transparency. Its members complain that fear keeps membership numbers low. In fact, leaders on both sides were shot in the last four years, and police continue to investigate the murders. Unfortunately, internal violence within the camelo reinforces the perception of piracy as dangerous, completing a vicious circle. State planners informed me, off the record, that they were unable to formalize more fully the camelódromo because of the presence of "pirated products" there. They noted that the presence of such products causes police raids. This, in turn, creates fear and a greater desire for acceptance, which more formality might bring. Yet the desire for formality itself causes violence, because there are disagreements about its form and content.

Split subjectivity within the camelódromo is multilayered. Although the workers and customers of the camelódromo may be proud of aspects of their piracy, treating it as a kind of social banditry that counteracts the price gouging of international corporations, they also strive for formalization. Their split subjectivity also reveals itself on other levels. Despite their pleasure at receiving cheaper goods and better service, customers are beginning to have reservations about buying from the camelódromo. Lest the FNCP ads appear solely as corporate ideology, more buyers 42 at the camelódromo over the last decade have described a "sad" feeling about their 
pirated purchases, fearing that they are stealing from their favorite band or robbing the manufacturer.

The instability of subjectivity at this ethnographic site also appears in the structure of voicing that buyers and sellers apply to what they are doing at the camelódromo. The commodities consumed within the camelódromo constantly beg the truth of their claims about their own provenance. Here, among the camelôs, the pirated good is often described as "just as good as" the legitimately circulated one. Some go further. One storeowner, whose shop repairs computers using cheap Chinese parts, proudly pointed to the size of the embroidered dragon on the back of his jeans. He informed me that because this dragon was even larger than the one on the licit pair, his jeans were "even better than the originals." But such arguments always position themselves in opposition to claims to the contrary. The buyers and sellers of "pirated products" continually strive for "good quality." At the same time, they know that the actors and institutions affiliated with the FNCP, and the state apparatuses that both support the FNCP and take bribes from the camelô, think their production and consumption is not only cheap but also dangerous. The position taken by the camelô here is inherently defensive, therefore, and his approach to what he does is deeply divided. In this way, just as those producing the FNCP's advertising campaign momentarily support piracy, the camelôs increasingly pine for commodities whose magic derives from their attentiveness to IP. Looking up from the central intersection of Campinas's camelódromo, passersby can see a large advertising surface on a nearby building, which, because I began research in Campinas 12 years ago, has presented glossy ads for foreign cars (Hondas, Fiats, and Fords), high-end shampoos (Vidal Sassoon), and digital cameras (Sony).

\section{FOR ENGLISH EYES, DIVIDED}

We have heard accusations on all sides. For the NGOs, except in revealing lapses, the villains are those who facilitate "piracy": buyers, sellers, suppliers, thieves, smugglers, and clandestine manufacturers. The mindset of the NGOs is often reflected in the state apparatuses and the media, which attack piracy. For the camelô, except, once again, for telling slips in which pure products are exactly what their advertisers claim them to be, the villains are foreign-funded NGOs who seek to malign their honest work, corporate monopolies insulating themselves from competition, and governmental agents who assist in these processes. For the camelô, these are pirates of another sort. So everyone is calling everyone else a pirate, which gives weight to the assertion that piracy seems to be "the definitive transgression of the information age" (Johns 2010:5). 
cuan_1125 can2008.cls December 10, 2011 19:39

CULTURAL ANTHROPOLOGY 27:1

However, my argument is that current neoliberal dependence on the concept of piracy is different from previous uses of the concept, and this has created a distinct form of what I call split subjectivity. In the 21 st century, IP policing and expansion, an emphasis on an individuated consumer, the rise of economic informality, and anxieties over digital copying have made piracy the indexical ground on which circulatory legitimacy rests. IP's proponents - property lawyers, pharmaceutical companies, music and film companies, and so forth — strive to apply IP to as broad a range of human practices as possible, claiming that it is a fundamental and transhistorical right. However, we see here that IP defines itself locally in response to piracy, fashioning an ethics of accumulation - a moral scheme for deciding who gets to maximize economic potential and who does not. These days, IP proscriptively distinguishes the formal (legitimate) from the informal (pirated) and provides both discursive and logistical supports for maintaining that distinction.

The split subjectivities on display here reveal a central paradox of neoliberalism. Consumers, producers, and suppliers oriented toward consumer goods are constantly required to do two things at the same time. First, they are required to permit commodities to signify only in terms of their circulatory legitimacy. At the same time, however, they are asked to buy as cheaply as possible. Although it is tempting to view these opposed positions as the reflex of global forces, a notion seemingly abetted by the knowledge that the FNCP's funding comes almost entirely from abroad, the evidence here tirelessly returns us to the local roots of piracy's centrality to neoliberal fields of consumption. Both intimate (it's a Brazilian embarrassment) and critical (it's Brazil's finger in the eye of multinationals) stances on piracy approach it as a local failure or success, grounded in durable discourses of mixture and purity. In the case of the NGOs, the argument is that in other countries people actually value IP. People don't steal from one another. North Americans, for instance, leave intact the appropriate boundaries between forms of production and circulation, and thus they provide incentives for invention and creativity. Among the camelôs, the average Brazilian's propensity to enact a creative solution by violating boundaries provides the necessary response to international monopolies and their local collaborators. Here, the camelô would assert, is how we avoid paying the ridiculous prices that citizens of First World countries don't have to pay.

A Brazilian expression that something is done to the letter of the law "only so that the English will see" illustrates these localized tensions over boundedness and the way in which piracy brings these tensions to the fore in late neoliberal 44 times. Folk etymologies of the expression para inglês ver differ. Some say it first 
occurred in the 1800s during the British blockade of slave ships off the Brazilian coast that would attempt to disguise themselves as regular trading vessels; others say it was born in the Brazilian interior when British rail companies watched over their laborers. Current invocations channel the tacit assumption that things will get jumbled here, in this place. And the fact that corners will be cut and mingling will take place is embarrassing and locally appropriate at the same time. This is something that foreigners just won't understand, so instead we show them something that seems to fit their rules.

The simultaneously "culturally intimate" and "critical" poetics of recognition in this expression, emplotted within late colonial practice but invoked today to describe phenomena like the ads of the FNCP and the formalizations of the camelódromo, underscore the current importance of piracy. The fields of cultural production on which consumption relies currently reinforce a tension between purity and its violation. Piracy thus helps us trace the local limits of practice on which neoliberal circulation grounds itself. Piracy creates the possibility of consummated exchange, while dividing an anxious neoliberal subject in two.

\begin{abstract}
Understanding current neoliberalism in Brazil requires an analysis of the piracy that has been going on there since at least the 1970s. Early phases of neoliberalism shrank the state, liberalized markets, and privatized resources. Current forms of neoliberal practice are characterized by large informal economies, intellectual property (IP), circulatory "legitimacy," individualized consumption, and the reproductive fidelities of digital technology. This current combination places the unauthorized production, sale, and use of goods (often referred to as "piracy") at the center of the forms of exchange on which the modern Brazilian economy relies. Purchases may be viewed as degraded or redemptive by having been mediated through "piracy," and most consumers of public culture are referred to at some point by the culture industry as "pirates." The anxious subjectivities that result from piracy's emerging centrality are here analyzed at two contrasting Brazilian sites. The first is an NGO that polices violations of IP. The second is an informal marketplace in the state of São Paulo where workers strive for "competitive pricing." In both of these sites, piracy simultaneously elucidates international discourses while it inscribes local approaches to mixture and boundary violation. At some moments, piracy appears as a distinctly Brazilian "embarrassment." In others, it is a typically creative Brazilian solution to the problem of unfair international markets. [piracy, neoliberalism, intellectual property, informal economies, camelô, Brazil]
\end{abstract}

\title{
NOTES
}

1. All proper names are pseudonyms.

2. Reals are the Brazilian currency, currently valued at approximately $\$ 0.50$. 
3. For a critique of these "studies," see Sell (2009).

4. ACTA is a broad IP treaty in the process of being ratified by the United States, Japan, and the European Union. It promises to radically increase global scrutiny of IP infractions. For a critique of the policy along anthropological lines, see Dent (2010).

5. For more on the use of piracy to decide participation in previous eras, see Johns (2010) and Darnton (2003).

6. My interest in subjectivities continues a long-standing anthropological interest in modes of perception, self-understanding, and affect by way of subject positions and position takings (see Bourdieu 1977; Geertz 1973).

7. The necessity of localizing Brazilian economic practice is not particularly new. It was worked on by theorists of "associated-dependent development" in the late 1970s and early 1980s (Cardoso 1989).

8. The presidency of the organization changed in 2010, although Roberto continues to play an active role.

9. For more on the layout of the Campinas camelódromo see Camilo Albuquerque de Braz's excellent thesis (2002)

10. There is currently a battle over the STEIC acronym. The older organization is now the Society of Workers of the Informal Economy of Campinas, while the new union calls itself the Union (or sindicato) of Workers of the Informal Economy of Campinas. Both spell STEIC.

\section{REFERENCES CITED}

Allison, A.

2010 The Cool Brand, Affective Activism and Japanese Youth. Theory, Culture and Society 26(2-3):89-111.

Andrade, O.d.

1970 [1925] Obras Completas - Oswald de Andrade. Rio de Janeiro, Civilização Brasileira.

Biehl, J.

2006 Pharmaceutical Governance. Global Pharmaceuticals: Ethics, Markets, and Practices. A. Petryna, A. Lakoff, and A. Kleinman, eds. Durham, NC: Duke University Press.

Bourdieu, P.

1977 Outline of a Theory of Practice. Cambridge, Cambridge University Press.

Braz, C. A. d.

2002 Camelôs no Sindicato: Etnografia de um conflito no universo do trabalho. Instituto de Filosofia e Ciências Humanas-Departamento de Antropologia. Campinas, SP, UNICAMP. BA: 126.

Brown, $M$

2003 Who Owns Native Culture? Cambridge, MA: Harvard University Press.

Caldeira, $\mathrm{T}$.

2001 City of Walls: Crime, Segregation and Citizenship in São Paulo. Berkeley, University of California Press.

Cardoso, F. H.

1989 Associated-Dependent Development and Democratic Theory. Democratizing Brazil: Problems of Transition and Consolidation. A. Stepan, ed. Pp. 299-326. New York, Oxford University Press.

Centeno, M. A., and A. Portes

2006 The Informal Economy in the Shadow of the State. Out of the Shadows: The Informal Economy and Political Movements in Latin America. P. Fernández-Kelly and J. Sheffner. Princeton: Princeton University Press.

Collins, J.

2004 "X Marks the Spot": Protestant Ethics and Bedeviling Mixtures in a Brazilian 
in the Age of Public Culture. A. Shryock, ed. Pp. 191-224. Stanford: Stanford University Press.

Comaroff, J., and J. L. Comaroff

2001 Millennial Capitalism: First Thoughts on a Second Coming. Millennial Capitalism and the Culture of Neoliberalism. J. Comaroff and J. L. Comaroff, eds. Pp. 1-56. Durham, NC: Duke University Press.

Condry, I.

2004 Cultures of Music Piracy: An Ethnographic Comparison of the US and Japan. International Journal of Cultural Studies 7(3):343-363.

DaCunha, E.

1944 Rebellion in the Backlands. Chicago: University of Chicago Press.

DaMatta, R.

1979 Carnivals, Rogues and Heroes: An Interpretation of the Brazilian Dilemma. Notre Dame, IN: University of Notre Dame Press.

Darnton, $\mathrm{R}$

2003 The Science of Piracy: A Crucial Ingredient in Eighteenth-Century Publishing. In Studies on Voltaire and the Eighteenth Century, 12. Pp. 3-29. Oxford: Voltaire Foundation.

Dent, A. S.

2009 River of Tears: Country Music, Memory, and Modernity in Brazil. Durham, NC, Duke University Press.

2010 Flouting the Elmo Necessity and Denying the Local Roots of Interpretation: Anthropology's Quarrel with ACTA. Program on Information Justice and Intellectual Property Research Paper Series. Washington, DC: American

Dibbell, J. University Washington College of Law.

2004 We Pledge Allegiance to the Penguin, and the Intellectual Property Regime for which He Stands. One Nation, Under Linux, with Free Music and Open Source Software for All. Welcome to Brazil! Wired 12(November).

Freyre, G.

1986 [1935] The Masters and the Slaves = Casa-Grande and Senzala: A Study in the Development of Brazilian Civilization. Berkeley: University of California Press.

Friel, C.

2007 The High Costs of Global Intellectual Property Theft: An Analysis of Current Trends, The Trips Agreement, and Future Approaches to Combat the Problem. Wake Forest Intellectual Property Law Journal 7(2):212-249.

Gay, R.

2006 The Even More Difficult Transition from Clientelism to Citizenship: Lessons From Brazil. In Out of the Shadows: The Informal Economy and Political Movements in Latin America. P. Fernández-Kelly and J. Sheffner, eds. Pp. 195-217. Princeton: Princeton University Press.

Geertz, C.

1973 Deep Play: Notes on the Balinese Cockfight. In The Interpretation of Cultures. Pp. 412-453. New York: Basic.

Heller-Roazen, D.

2009 The Enemy of All: Piracy and the Law of Nations. New York: Zone.

Herzfeld, $M$.

1996 Cultural Intimacy: Social Poetics in the Nation State. London: Routledge.

Hobsbawm, E.

2000 Social Banditry. New York: New Press.

Holanda, S. B. d.

1995 Raízes do Brasil. São Paulo: Companhia das Letras. 
Houaiss

2001 Dicionário Eletrônico. 1.1. CCCC: Rio de Janeiro: Objetiva.

Johns, A.

2010 Piracy: The Intellectual Property Wars from Gutenberg to Gates. Chicago: University of Chicago Press.

Larkin, B. 2008 Signal and Noise: Media, Infrastructure, and Urban Culture in Nigeria. Durham, NC: Duke University Press.

Lessig, L. 2004 Free Culture: The Nature and Future of Creativity. New York: Penguin.

Lobão, N. G., Jr., Nehemias Gueiros Jr., and Zeca Baleiro 2000 O som da ética. Caros Amigos 3:22-28.

Manning, P., and A. Uplisashvili

2008 "Our Beer": Ethnographic Brands in Postsocialist Georgia. American Anthropologist 109(4):626-641.

Matory, L.

2004 Sexual Secrets: Candomblé, Brazil, and the Multiple Intimacies of the African Diaspora. In Off Stage/On Display: Intimacy and Ethnography in the Age of Public Culture. A. Shryock, ed. Pp. 157-190. Stanford: Stanford University Press.

Morris, R.

2001 Modernity's Media and the End of Mediumship? On the Aesthetic Economy of Transparency in Thailand. In Millennial Capitalism and the Culture of Neoliberalism. J. Comaroff and J. Comaroff. Pp. 192-214. Durham, NC: Duke University Press.

O’Dougherty, M.

2002 Consumption Intensified: The Politics of Middle-Class Daily Life in Brazil. Durham, NC: Duke University Press.

Oliven, R. G.

1992 A Parte e o Todo: A Diversidade cultural no Brasil-Nação. Petrópolis: Editora Vozes.

Olson, B., M. Graham, John Maltbie, and Ron Epperson

2007 The 10 Things Every Practitioner Should Know About Anti-Counterfeiting and Anti-Piracy Protection. Journal of High Technology Law 7(106):106-172.

Ortner, S.

2005 Subjectivity and Cultural Critique. Anthropological Theory 5(1):31-52.

Parker, R.

2009 Bodies, Pleasures, and Passions: Sexual Culture in Contemporary Brazil. Nashville, TN: Vanderbilt University Press.

Phillips, T.

2005 Knockoff: The Deadly Trade in Counterfeit Goods: The True Story of the World's Fastest Growing Crime Wave. London: Kogan Page.

Schneider, J., and P. Schneider

2008 The Anthropology of Crime and Criminalization. Annual Review of An-

1992 Brazilian Culture: Nationalism by Elimination. In Misplaced Ideas. Pp.

Sell, S. K. 1-19. London: Verso.

2009 The Global IP Upward Ratchet, Anti-Counterfeiting and Piracy Enforcement Efforts: The State of Play. PIJIP Research Paper, 15. Washington, DC: American University Washington College of Law.

Soto, H. D.

1989 The Other Path: The Economic Answer to Terrorism. New York: Basic. 
Storper, M.

2001 Lived Effects of the Contemporary Economy: Globalization, Inequality, and Consumer Society. In Millennial Capitalism and the Culture of Neoliberalism. J. Comaroff and J. L. Comaroff, eds. Pp. 88-124. Durham, NC: Duke

veja University Press.

Veloso, C.

2002 Tropical Truth: A Story of Music and Revolution in Brazil. New York: Alfred A. Knopf.

Wang, S.

2003 Framing Piracy: Globalization and Film Distribution in China. Lanham, MD: Roman and Littlefield.

Weber, M.

1958 The Protestant Ethic and the Spirit of Capitalism. New York: Charles Scribner's Sons.

Editors' Notes: Cultural Anthropology has published many articles on intellectual property, including, Gabriella Coleman's “Code is Speech: Legal Tinkering, Expertise, and Protest Among Free and Open Source Software" (2009), Christopher M. Kelty, Michael M. J. Fischer, Alex "Rex" Golub, Jason Baird Jackson, Kimberly Christen, Michael F. Brown, and Tom Boellstorff's "Anthropology of/in Circulation: The Future of Open Access and Scholarly Societies" (2008), and Christopher Kelty's "Geeks, Social Imaginaries, and Recursive Publics" (2005).

Cultural Anthropology has also published articles on South America. See, for example, John Collins' ““'But What If I Should Need to Defecate in Your Neighborhood, Madame?": Empire, Redemption, and the "Tradition of the Oppressed" in a Brazilian World Heritage Site" (2008), Charles Briggs' "Mediating Infanticide: Theorizing Relations Between Narrative and Violence” (2007), and Steven Rubenstein's “Circulation, Accumulation, and the Power of Shuar Shruken Heads" (2007). 